\author{
E. Tasak $^{1 *}$, A. Ziewiec ${ }^{1}$, A. Zielińska-Lipiec ${ }^{1}$, K. Ziewiec ${ }^{2}$ \\ ${ }^{1}$ AGH University of Science and Technology, Faculty of Metals Engineering and Industrial \\ Computer Science, Mickiewicza 30, 30-059 Kraków, Poland \\ ${ }^{2}$ Pedagogical University of Cracow, Faculty of Mathematics, Physics and Technical Science, \\ Institute of Technology, Podchorażych 2, 30-084 Kraków, Poland \\ *tasak@agh.edu.pl
}

\title{
PROBLEMS OF PAD WELDING STRUCTURAL STEELS WITH MARTENSITIC FILLER METAL
}

\begin{abstract}
There is a problem in obtaining a suitable impact strength of the padding weld after cladding with a martensitic filler metal. Too low annealing temperature below $580^{\circ} \mathrm{C}$ and the excessive annealing temperature above $650^{\circ} \mathrm{C}$ do not provide adequate impact strength of the padding weld. A heat treatment technology for mixed joints has been developed based on the results of the microscopic observations, X-ray diffraction measurements and transmission electron microscope examination. The problem was identified and a special technology of heat treatment for the dissimilar joint was elaborated. This technology provides a high impact resistance of the padding weld and an appropriate properties of the base material.
\end{abstract}

Keywords: pad welding, reversed austenite, X3CrNiMo13-4 martensitic steel, $H_{p}$ parameter

\section{INTRODUCTION}

Martensitic steels containing $13 \% \mathrm{Cr}$ are widely used in the industry due to their high corrosion resistance and strength. Their microstructure vary from pure ferrite to martensite depending on the carbon content. These steels can be divided into four groups [1]:

- the ferritic steels for general use,

- the steels with a low martensite content,

- the steels with soft martensite,

- the new supermartensitic steels.

The strength range for each of these groups depends on the heat treatment applied. During solidification of these steels the primary phase precipitating from the liquid is $\delta$ ferrite. This is particularly important in the case of joint not subjected to high-temperature heat treatment homogenizing the chemical composition. Differences in the chemical composition of the weld cause a change in the kinetics of the transformation during cooling and this can result in the occurrence of microstructure components that adversely affect both corrosion and strength. The effect of strength changes during cooling is also observed in the other groups of steels i.e. 
in structural steels [2] and in advanced micro-alloyed steels and alloys for high-temperature and high-pressure applications [3, 4].

Supermartensitic stainless steels are based on grades containing $13 \% \mathrm{Cr}$, but they have a lower carbon content and additions of $4 \div 6 \% \mathrm{Ni}$ and $0.5 \div 1.5 \mathrm{Mo}$. These steels have a very good resistance to general corrosion as well as cracking caused by stress corrosion in an acidic environment $\left(\mathrm{H}_{2} \mathrm{~S}\right)$. They also present high resistance to cavitation and abrasion in high humidity conditions. For this reason, they were used in such applications as: parts of water turbines, pumps and valves in power plants, drilling heads in the oil industry, etc. $[1,5,6,7]$.

The influence of heat treatment on the microstructure and mechanical properties of supermartensitic steels has been studied by many authors [8-12]. They found that after tempering the steel microstructure consists of tempered martensite and residual austenite. The amount of austenite decreases above $700^{\circ} \mathrm{C}$. De Sanctis [13] noted that relatively low $\mathrm{A}_{\mathrm{c} 1}$ temperatures induce the formation of an austenitic phase above $600^{\circ} \mathrm{C}$ during tempering. The formed reverse austenite tends to be unstable during cooling, which contributes to increasing the final hardness by converting austenite to virgin (fresh) martensite. Similar behavior of austenite is also observed in other martensitic steels [14, 15].

In case of welding the X3CrNiMo13-4 steels, low-carbon binders of the EN 12072: G 13 4 grade are used. After welding the microstructure of these steels obtained after tempering contain a lath martensite, austenite and a small amount of residual ferrite. Weldability of these steels is good due to the formation of ductile, low-carbon martensite in both the weld and the heat affected zone (HAZ) $[16,17]$. This reduces the susceptibility to hydrogen cracking. The low content of $\delta$ ferrite reduces the tendency to grain growth. However, in spite of such good properties, the attention should be paid to the hydrogen content in the weld, which should not exceed $5 \mathrm{ml} / 100 \mathrm{~g}$ of weld metal. In the petrochemical and mining installations exposed to hydrogen sulfide, high impact strength and low hardness are important. In order to prevent cold cracking caused by the hydrogen sulphide, the hardness of the HAZ and the welded joint should be lower than $23 \mathrm{HRC}$ and the impact energy at room temperature have to be higher than $50 \mathrm{~J}$.

It is important to choose the appropriate heat treatment parameters after welding to ensure optimum plastic properties and a minimum hardness. In the case of pad welding of structural P265GH steels with a binder corresponding to the composition of X3CrNiMo13-4 steel, the designers usually recommended a stress relief annealing in the range $520 \div 570^{\circ} \mathrm{C}$. Such treatment guarantees obtaining correct properties of the pad welded part, however it does not provide the required impact strength and hardness of the pad welds of the martensitic steel. Due to the problems with obtaining the required plastic properties and hardness, an attempt was made to test the $\mathrm{X} 3 \mathrm{CrNiMo13-4}$ steel pad welds.

\section{EXPERIMENTAL}

The research on the influence of heat treatment on the properties of padding was carried out on pad welded samples made of the P255GH steel elements cut from power equipment parts. The pad welds were produced using GMA method applying Thermanit 13/04 wire in M13 mixture. The main purpose of the research was to explain the mechanism of changes in the properties of pads subjected to heat treatment process and to determine the conditions of heat treatment ensuring hardness of the pad weld lower than $23 \mathrm{HRC}$ and the highest possible 
impact strength. The orientation of the pad weld in the P265GH steel element and the cutting of the impact test samples are shown in Figure 1.

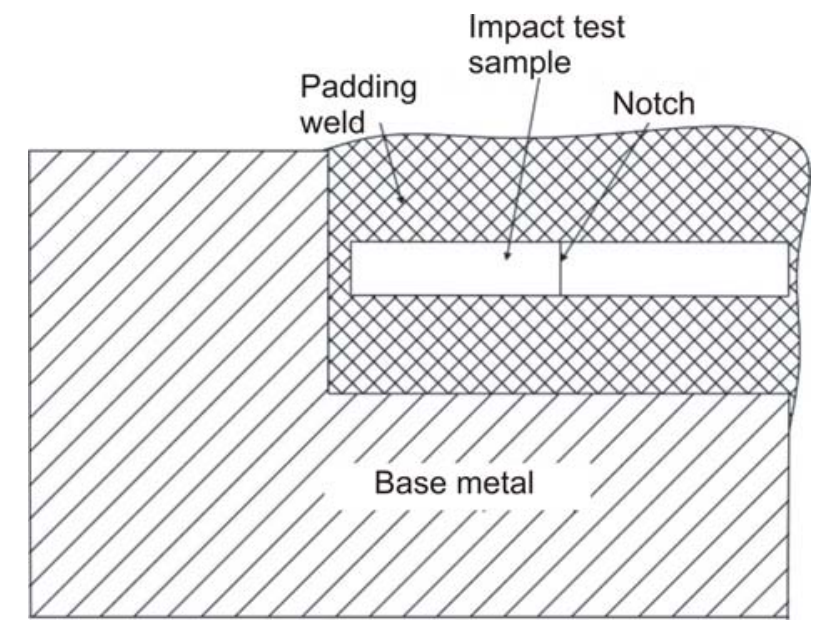

Fig. 1. The schematic diagram of the part with the pad welding and the method of cutting out impact samples

The impact test samples (without $\mathrm{V}$ notch) were heat treated at $580 \div 690^{\circ} \mathrm{C}$ for $2,5,10$ and 20 hours. After heat treatment, the $\mathrm{V}$ notches were cut and the samples were broken at $+20^{\circ} \mathrm{C}$ using Charpy impact test. For each individual temperature and time of the heat treatment the three samples were used. The values of the impact energy are the average from three measurements. In addition to testing the impact strength of the weld pads, hardness was measured using Rockwell (HRC) and Vickers (HV) using 294,3 N load. The results of hardness are calculated as the average of nine measurements. Both methods: Rockwell and Vickers hardness measurements were used. The welded joint hardness is measured by the Vickers method, while the acceptance criteria of the welded construction usually give the HRC number as a reference value.

Annealing temperatures and heat treatment times were varied throughout the investigations. Therefore in order to determine the effect of these parameters on the properties, the $\mathrm{H}_{p}$ parameter was calculated. The references $[18 \div 21]$ showed that the properties of steel after heat treatment are described by a specific function of the $\mathrm{H}_{\mathrm{p}}$ parameter.

$$
\mathrm{H}_{\mathrm{p}}=\mathrm{T}(20+\log \mathrm{t}) \cdot 10^{-3}
$$

where:

$$
\begin{aligned}
& \mathrm{T} \text { - annealing temperature, } \mathrm{K} \\
& \mathrm{t} \text { - annealing time at given temperature, hours }
\end{aligned}
$$

Microstructure of the pad weld samples was investigated using LM light microscope Leica DMLM. TEM microstructural analysis was carried out using a transmission electron microscope JEOL 200CX. The XRD studies were performed on a Siemens D500 Diffractometer, using the monochromatic radiation of a copper X-ray tube $\left(\lambda_{\mathrm{Cu}} \mathrm{K} \alpha=1.54 \AA\right)$. Diffraction pattern was determined with the use of Bragg-Brentano method, using stepcounting $\left(\Delta 2 \theta=0.02^{\circ}\right.$, time per step $\left.\tau=5 \mathrm{~s}\right)$ in the angle range $2 \theta$ from $35^{\circ}$ to $90^{\circ}$. 


\section{RESULTS}

The values of the impact energy of the pad welds and corresponding hardness measured by Rockwell and Vickers methods as a function of $\mathrm{H}_{\mathrm{p}}$ parameter are presented in Figures 2 and 4. The dependence of the impact energy and the hardness of the pad weld sample on annealing treatment temperature for 5 hours are illustrated in Figures 3 and 5 . These figures show that the lowest hardness and the highest impact energy is obtained for $\mathrm{H}_{\mathrm{p}}$ parameter between 18 and 19. Assuming the parameter $\mathrm{H}_{\mathrm{p}}=18.5$, it can be calculated that at $600^{\circ} \mathrm{C}$, the minimum annealing time to obtain a hardness of $275 \mathrm{HV}$ is about 11 hours, while for $620^{\circ} \mathrm{C}$ it is about 5 hours. Thus, heat treatment after welding in the temperature range 600 to $620^{\circ} \mathrm{C}$ for 5 hours will ensure a maximum impact energy of $90 \div 100 \mathrm{~J}$ (Fig. 5). For the parameters of heat treatment mentioned above a minimum hardness of $275 \mathrm{HV}$ is obtained (Fig. 3).

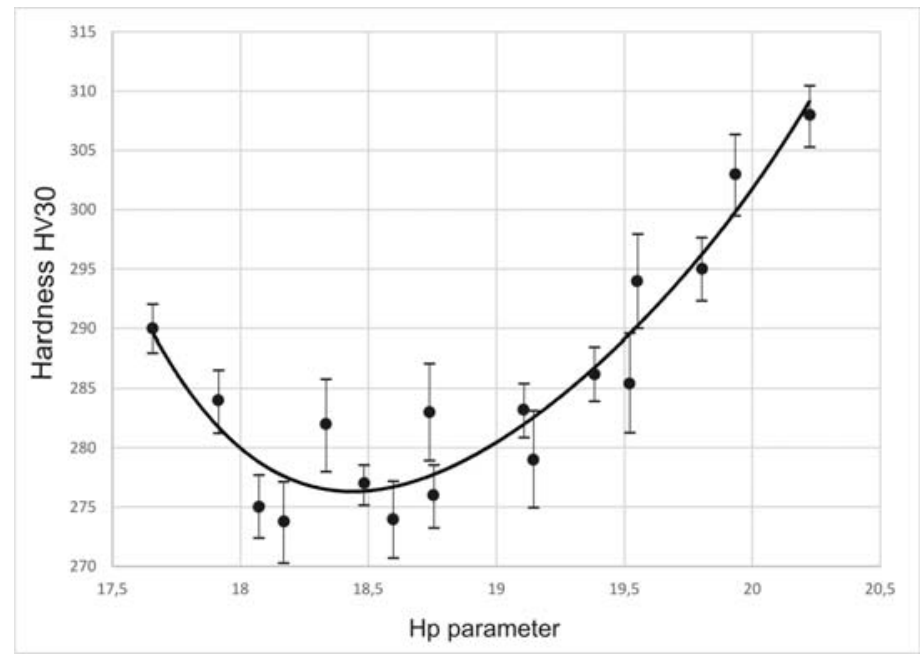

Fig. 2. The dependence of HV30 hardness on the Hp parameter. The averaged experimental data points are marked as black dots, the error bars are shown on the graph. The thick solid line represents the resulting fitting curve (HV30=252973.1-51841.46 $\cdot \mathrm{Hp}+3992.741 \cdot \mathrm{Hp} 2-136.8755 \cdot \mathrm{Hp} 3+1.762915 \cdot \mathrm{Hp} 4)$

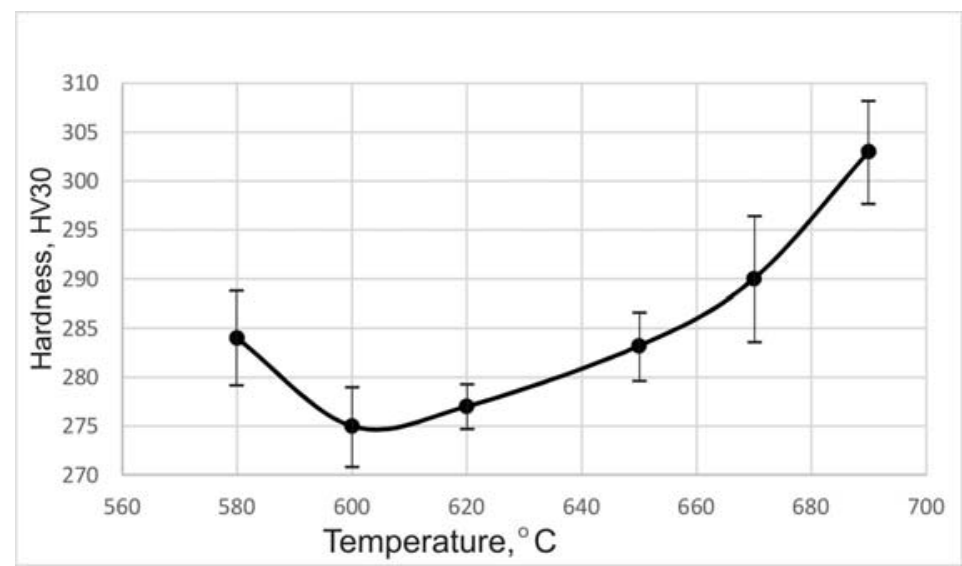

Fig. 3. The dependence of hardness on the annealing temperature for 5 hours 


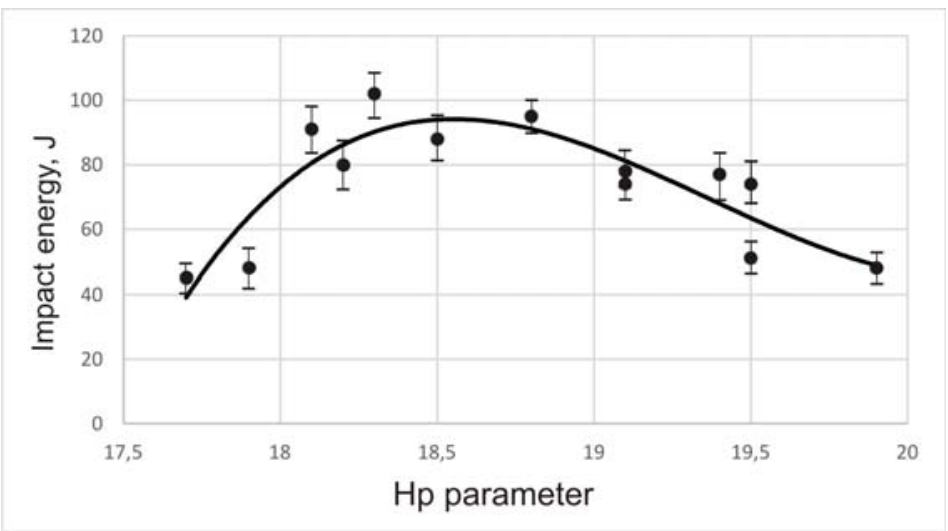

Fig. 4. The dependence of the impact energy on the Hp parameter

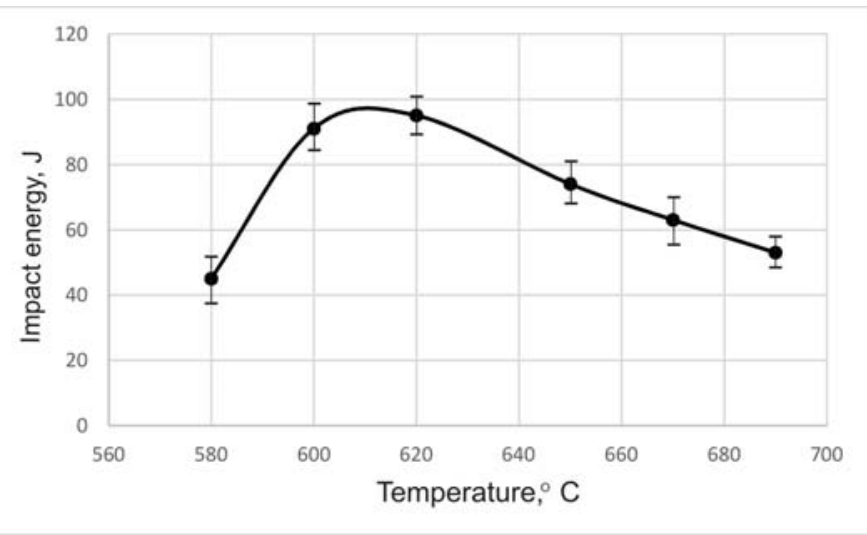

Fig. 5. The dependence of the impact energy on the annealing temperature

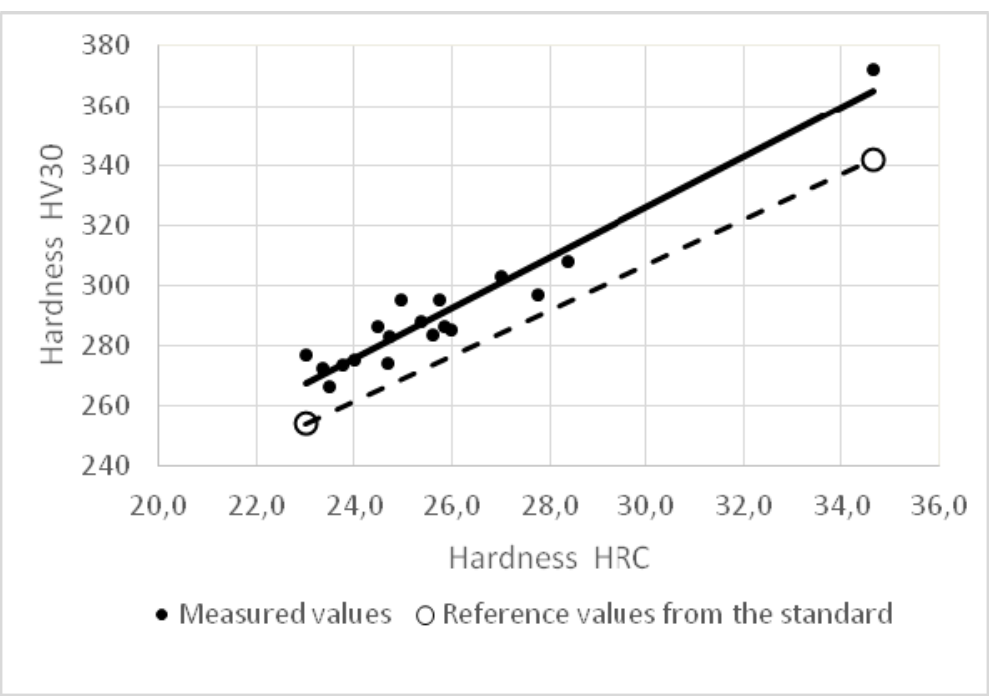

Fig. 6. Relationship between HV30 hardness and HRC hardness 
Hardness measurement results allowed to make a graph of the relationship between hardness measured by the Vickers and Rockwell method. This relationship is shown in Fig. 6 and it can be seen that there is no match between the obtained hardness results and the relationship given in the EN-ISO 18265:2013.

Microscopic examination shows that there is martensite and $\delta$ ferrite located in the cores of the cells within the pad weld microstructure (Fig. 7). Annealing at the range of temperatures of $580 \div 690^{\circ} \mathrm{C}$ does not change the microscopic image of the structure significantly. The only change concerns the blur of the martensite - $\delta$ ferrite interface boundary as a result of diffusion processes (Fig. 8).

The XRD examinations showed that after pad welding only $\alpha$ phase (martensite and $\delta$ ferrite) is present. After annealing in the temperature range $580-620^{\circ} \mathrm{C}$, the additional phase is austenite. After annealing at higher temperatures, only $\alpha$ phase is present in the microstructure [21]. Figure 9 shows the changes of the austenite volume fraction in the microstructure.

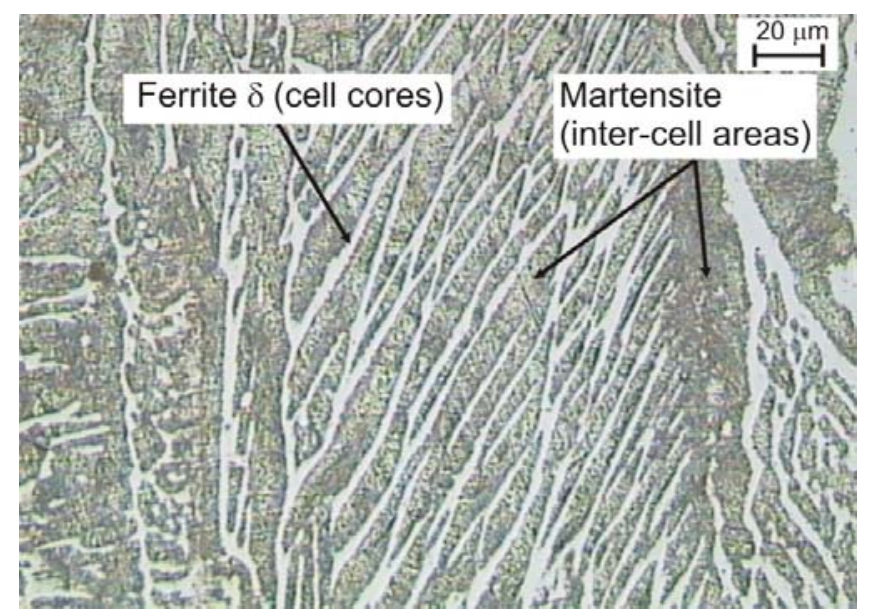

Fig. 7. Microstructure of the pad weld without heat treatment

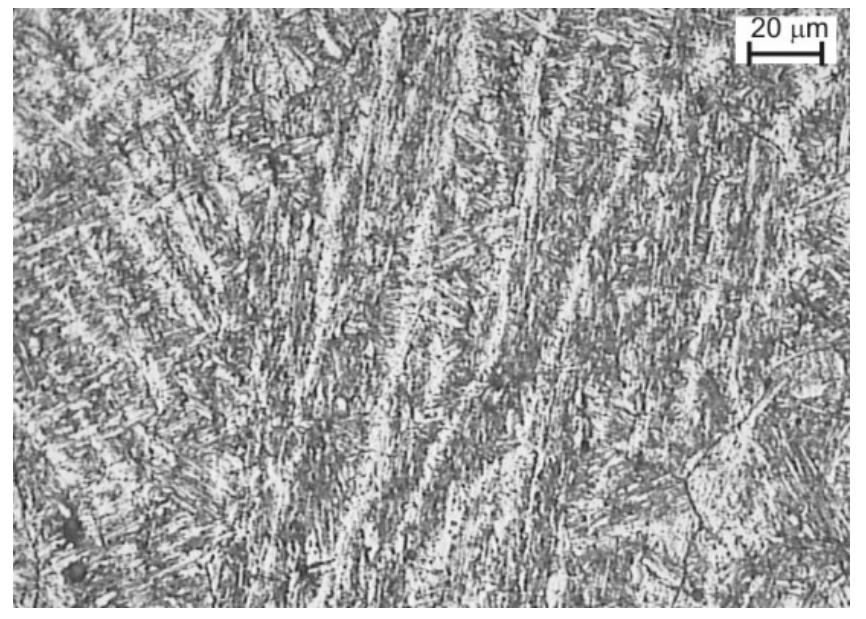

Fig. 8. Microstructure of padding weld after heat treatment (6000C, 10h) 


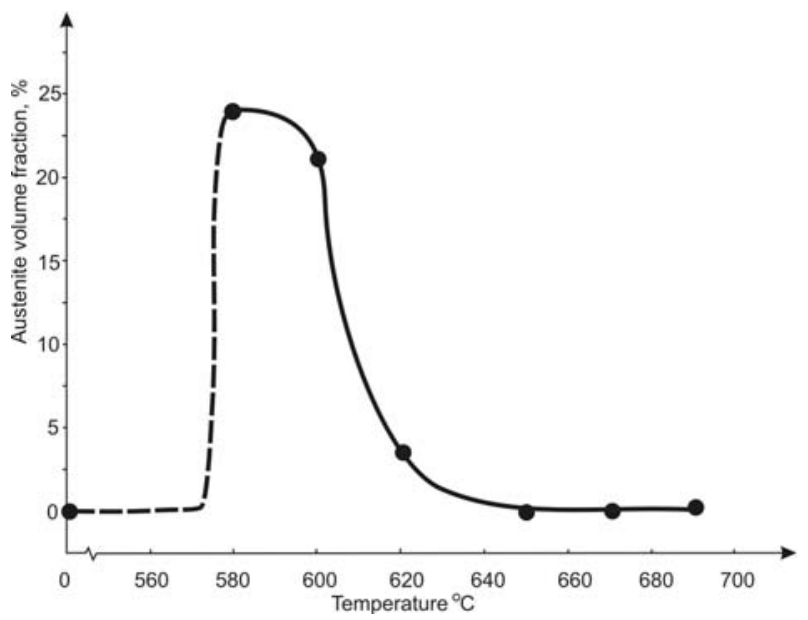

Fig. 9. Dependence on the austenite volume fraction on heat treatment temperature. Annealing time $10 \mathrm{~h}$

In order to explain the cause of the drop in impact strength after annealing at $650^{\circ} \mathrm{C}$ and above, the microstructure of the pad weld was examined in a transmission electron microscope using thin films. Examples of microstructures after pad welding and after heat treatment observed in an electron microscope are shown in Fig. 10. Observations of the microstructure show existence of a lath austenite after pad welding (Fig. 10a). After heat treatment at $580 \div 620^{\circ} \mathrm{C}$, austenite occurs in the microstructure between the laths of tempered martensite (Fig. 10b, c). After annealing at higher temperatures, austenite does not occur, whereas there is "fresh" martensite between the laths of tempered martensite (Fig. 10d).
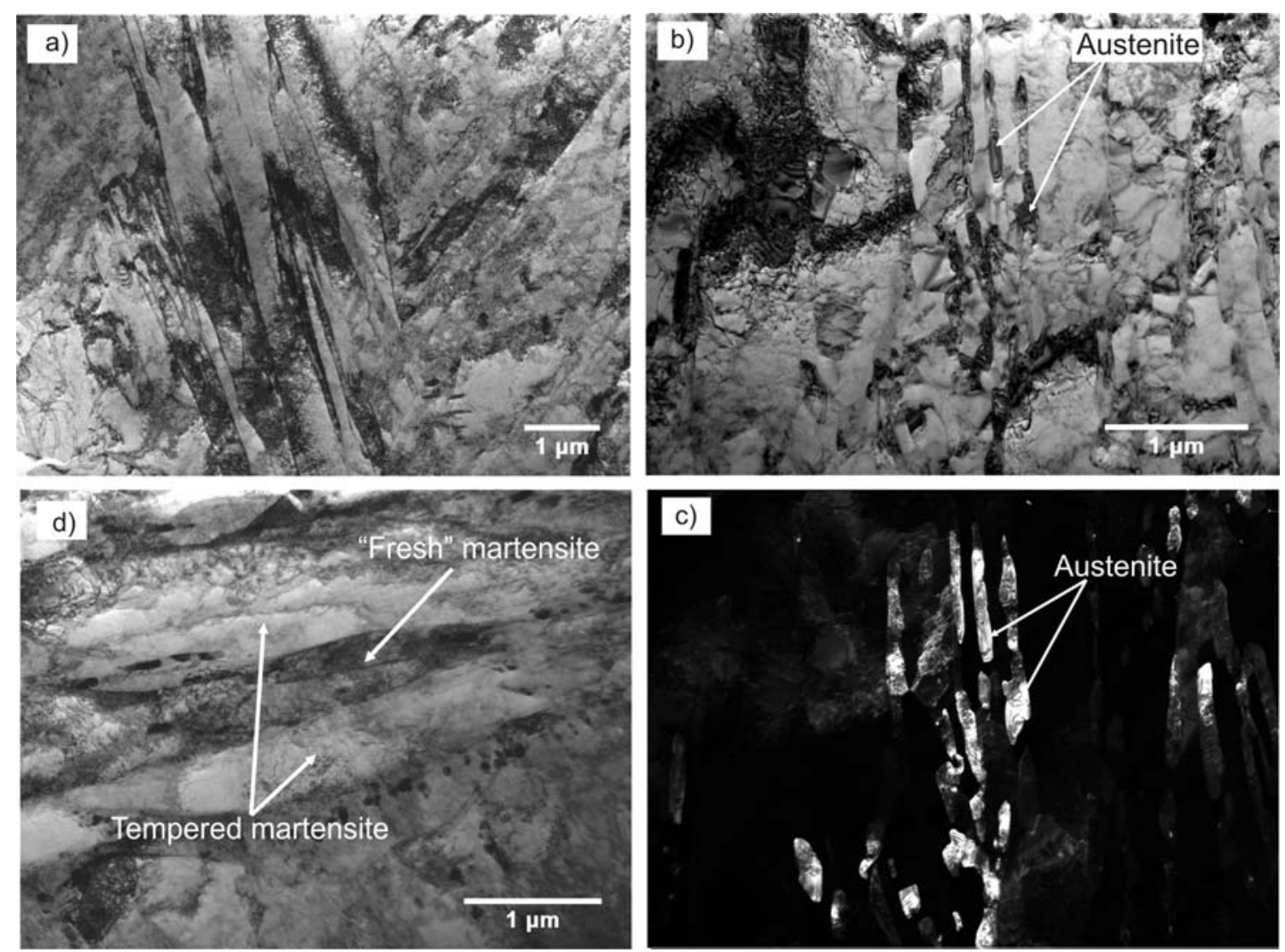

Fig. 10. Padding weld microstructure observed in a transmission electron microscope: a) lath martensite after pad welding, b - lath martensite with austenite after heat treatment at $600^{\circ} \mathrm{C}$ for $10 \mathrm{~h}, \mathrm{C}$ - austenite in the dark field contrast, $\mathrm{d}$ - tempered martensite and "fresh" martensite after heat treatment at $670^{\circ} \mathrm{C}$ for 10 hours 


\section{DISCUSSION}

The investigations have shown that the highest impact strength is obtained in temperature range of $600 \div 620^{\circ} \mathrm{C}$ after 10 hours of annealing. An increase in temperature above this range causes a continuous drop in impact strength. The annealing time is of no great importance, as this decrease is observed both for the annealing time of 5 hours and 10 hours. Therefore, behavior of this material is discrepant to the generally known relationships for other groups of steels. The change in impact strength also involves a corresponding change in hardness. The minimum hardness of pad weld at the level of $23 \mathrm{HRC}(275 \mathrm{HV})$ is obtained after heat treatment in the same temperature range. However, below $600^{\circ} \mathrm{C}$ and above $620^{\circ} \mathrm{C}$, the hardness is higher. Considering the combined effect of temperature and time $\left(\mathrm{H}_{\mathrm{p}}\right.$ parameter), it can be concluded that $\mathrm{H}_{\mathrm{p}}$ parameter is between 18 and 19 , the impact energy has a value of 90 to 100J (Figure 4). Low impact strength and high hardness after tempering up to $580^{\circ} \mathrm{C}$ can be explained by too slow diffusion process and a large dispersion of carbides. On the other hand, the decrease in impact energy and increase in hardness associated with the increase of the annealing temperature above $620^{\circ} \mathrm{C}$ can be explained as follows: There is a large segregation of alloying elements, especially nickel, in the X3CrNiMo13-4 steel padding welds. The ferritic cores of cells (marked in Fig. 7), contain $13.7 \% \mathrm{Cr}$ and $3.76 \% \mathrm{Ni}$, while martensitic inter-cell areas contain $13.2 \% \mathrm{Cr}$ and $5.44 \% \mathrm{Ni}$ [22]. In Gooch research [7] it was shown that steel containing 3.8\% $\mathrm{Ni}$ has an $\mathrm{A}_{\mathrm{cl}}$ temperature of about $600^{\circ} \mathrm{C}$, whereas steel containing $6 \% \mathrm{Ni}$ has an $\mathrm{A}_{\mathrm{c} 1}$ temperature of about around $575^{\circ} \mathrm{C}$. Since there is around $5.5 \%$ of nickel in the microsegregation areas, at around $580^{\circ} \mathrm{C} \mathrm{a}$ local phase transformation takes place and austenite is formed. Carbon and nickel diffuse into the austenite areas. In the martensitic inter-cell areas with the increased nickel content (5.44\%), the $\mathrm{A}_{\mathrm{c} 1}$ temperature is lower than in the ferritic cell cores.

Extending the annealing time results in austenite saturation with nickel and carbon, and thus an increase in thermal stability. After cooling to ambient temperature, thermally stable austenite is not transformed into martensite. The presence of residual austenite between the martensite laths has a positive effect on the impact strength of the padding weld.

XRD phase analysis (Fig. 9) showed that after cooling from the tempering temperature of $580^{\circ} \mathrm{C}$ there is $24 \%$ residual austenite in the microstructure, while after cooling from $620^{\circ} \mathrm{C}$ there is only $3 \%$. The remaining austenite was transformed into "fresh" martensite. However, at $620^{\circ} \mathrm{C}$, the amount of "fresh" brittle martensite is small and does not significantly affect the impact strength and hardness increase. The increase of the annealing temperature results in a larger amount of austenite with a lower concentration of nickel and carbon, which reduces its thermal stability. After cooling, the tempered martensite and "fresh" martensite are formed. The annealing temperature of $690^{\circ} \mathrm{C}$ is so high that virtually all of the austenite is transformed into a "fresh" martensite. This results in a decrease of impact strength by almost half as compared to the impact strength obtained after annealing at $600^{\circ} \mathrm{C}$.

The EN-ISO 18265:2013 assumes that values of the hardness measured with different methods can be converted using appropriate tables. The tests carried out on the joints of martensitic steel showed that the dependences given in the standards are not correct. This is especially important in the case of pads or welds that are in contact with hydrogen sulfide. Hardness below 23HRC and high impact strength is required for these materials. In the welded and pad welded joints hardness measurements are made using the Vickers method. The conversion table presented in EN-ISO 18265:2013 gives that the hardness value of 23 HRC corresponds to Vickers hardness number $254 \mathrm{HV}$. On the other hand, in the present study, it was found that the hardness of $23 \mathrm{HRC}$ corresponds to $275 \mathrm{HV}$. The results obtained 
in the present work are confirmed by previous studies of Hayes and Patrick [23] and Gooch [7], who also showed that the results of hardness measurements with the conversion given in ASTME 140-88 and BS 860:1967 were not compatible. The acceptance criterion permitting martensitic chromium-nickel steel constructions to be allowed, should be based on the following conversion formula $23 \mathrm{HRC}=275 \mathrm{HV}$.

\section{CONCLUSIONS}

1. During solidification of GMA pad welds produced with Thermanit 13-4 wire in M13 mixture gas there is a clear segregation of alloy components. Ferritic cell cores contain more chromium and less nickel, while inter-cell regions are richer in nickel and poorer in chromium. The enrichment of inter-cell areas with nickel and carbon results in lowering the $\mathrm{A}_{\mathrm{c} 1}$ conversion temperature. For areas containing about $6 \% \mathrm{Ni}$, the $\mathrm{A}_{\mathrm{c} 1}$ temperature is about $580^{\circ} \mathrm{C}$.

2. The change of hardness and impact resistance of the $\mathrm{X} 3 \mathrm{CrNiMo13}-4$ padding welds with an increase in tempering temperature is not monotonic. The highest impact strength $(90 \div$ $100 \mathrm{~J})$ is obtained after tempering in the range of $600 \div 620^{\circ} \mathrm{C}$ for 10 hours. The highest toughness corresponds to the lowest hardness at $23 \mathrm{HRC}(275 \mathrm{HV})$. An increase in the tempering temperature above $620^{\circ} \mathrm{C}$, regardless of time, results in lower impact strength and higher hardness.

3. The hardness tests have shown that the dependence of $23 \mathrm{HRC}=253 \mathrm{HV}$ recommended in the case of pad welds made of X3CrNiMo13-4 steel according to the EN-ISO 18265:2013 standard is not correct. For these steels one should assume that 23HRC = $275 \mathrm{HV}$.

\section{AKNOWLEDGMENTS}

The research was carried out within the statutory research project no 16.16.110.663.

\section{REFERENCES}

1. Marshall A. W., Farrar J. C. M., Welding of ferritic and martensitic $11-14 \%$ Cr steels. Welding in the World, 45 (2001) 32-55.

2. Tuz L., Evaluation of microstructure and selected mechanical properties of laser beam welded S690QL high-strength steel. Advances in Materials Science, 18(3) (2018) 34-42.

3. Rakoczy Ł., Grudzień M., Tuz L., Pańcikiewicz K., Zielińska-Lipiec A., Microstructure and properties of a repair weld in a nickel based superalloy gas turbine component. Advances in Materials Science, 17(2) (2017) 55-63.

4. Pańcikiewicz K., Structure and properties of welded joints of 7CrMoVTiB10-10 (T24) steel. Advances in Materials Science, 18(1) (2018) 37-47.

5. Tavaresa S.S.M., Norisc L.F., Pardalb J.M., da Silvad M.R., Temper embrittlement of supermartensitic stainless steel and non-destructive inspection by magnetic Barkhausen noise. Engineering Failure Analysis Journal, 100 (2019) 322-328.

6. Foroozmehra F., Verremana Y., Chena J., Thibaultb D., Bocher P., Effect of inclusions on fracture behavior of cast and wrought $13 \% \mathrm{Cr}-4 \% \mathrm{Ni}$ martensitic stainless steels. Engineering Fracture Mechanics, 175 (2017) 262-278. 
7. Gooch G. T., Heat treatment of welded $13 \% \mathrm{Cr}-4 \% \mathrm{Ni}$ martensitic stainless steel for sour service. Welding Journal, 74 (1995) $213 \div 223$.

8. Liu Y., Ye D., Yong Q., Su J., Zhao K., Jiang W., Effect of heat treatment on microstructure and property of Cr13 super martensitic stainless steel. Journal Iron and Steel Research International, 18 (2011) 60-66.

9. Jiang W., Zhao K., Ye D., Li J., Li Z., Su J., Effect of heat treatment on reversed austenite in Cr15 super martensitic stainless steel. Journal Iron and Steel Research International, 20 (2013) 61-65.

10. Escobar J. D., Poplawsky J. D., Faria G. A., Rodriguez J., Ramirez A. J., Compositional analysis on the reverted austenite and tempered martensite in a Ti-stabilized supermartensitic stainless steel: Segregation, partitioning and carbide precipitation. Materials \& Design, 140 (2018) 95-105.

11. Wang P., Xiao N., Lu S., Li D., Li Y., Investigation of the mechanical stability of reversed austenitein $13 \% \mathrm{Cr}-4 \% \mathrm{Ni}$ martensitic stainless steel during the uniaxialtensile test. Materials Science \& Engineering A, 586 (2013) 292-300.

12. Zhang S., Wang P., Li D., Li Y., Investigation of the evolution of retained austenite in $\mathrm{Fe}-$ $13 \% \mathrm{Cr}-4 \% \mathrm{Ni}$ martensitic stainless steel during intercritical tempering. Materials \& Design, 84 (2015) 385-394.

13. De Sanctis M., Lovicu G., Buccioni M., Donato A., Richetta M., Varone A., Study of 13Cr-4Ni(Mo) (F6NM) Steel Grade Heat Treatment for Maximum Hardness Control in Industrial Heats. Metals, 7, 351 (2017) 1-14.

14. Ziewiec A., Zielińska-Lipiec A., Kowalska J., Ziewiec K., Microstructure Characterization of Welds in X5CrNiCuNb16-4 Steel in Overaged Condition. Advances in Materials Science, 19(1) (2019) 57-69.

15. Man C., Dong C., Kong D., Wang L., Li X. Beneficial effect of reversed austenite on the intergranular corrosion resistance of martensitic stainless steel. Corrosion Science, 151 (2019) 108-121.

16. Chellappan M., Lingadurai K., Sathiya P. Characterization and Optimization of TIG welded supermartensitic stainless steel using TOPSIS. Materials Today: Proc., 4 (2017) 1662-1669.

17. Tavares S.S.M., Silva M.B., de Macêdo M.C.S., Strohaecker T.R., Costa V.M. Characterization of fracture behavior of a Ti alloyed supermartensitic $12 \% \mathrm{Cr}$ stainless steel using Charpy instrumented impact tests. Engineering Failure Analysis, 82 (2017) 695-702Gulvin T., F.; Scott J. $\mathrm{i}$ inni: The influence of stress relief on the properties of $\mathrm{C}$ and $\mathrm{C}-\mathrm{Mn}$ pressure-vessel plate steels, J. West. Scott. Iron Steel Inst. 80 (1972-73) 149-175.

19. Lochhead J., C., Speirs A., The effects of heat treatment on pressure-vessel steels, J. West. Scott. Iron Steel Inst., 80 (1972-73) 188-219.

20. Watkins B. i inni Effects of prolonged stress relieving treatments on the properties of reactor pressure - vessel steels, British Weld. Journ., 10 (1963) 15-21.

21. Tasak E. The influence of heat treatment on the properties of joints, Przegląd Spawalnictwa 62 (1990) 1-4, in Polish.

22. Wątróbska B, Tasak E, Structure and properties of welded joints of chromium-nickel stainless steels containing soft martensite. Transactions of the Conference "Materials Engineering Yesterday, Today and Tomorrow" AGH, Krakow, 2005, 103-106, in Polish.

23. Hayes C., Patrick D. H., Hardness conversion data for CA6NM alloy. Metallography, 16 (1983) 229-235. 